\title{
PRIMJENA ZAHJEVA ZA IZVANREDNO PREISPITIVANJE ZAKONITOSTI PRAVOMOĆNE PRESUDE
}

\author{
UDK: $342.9(497.5)$ \\ Pregledni rad \\ Primljeno: 15. 12. 2016.
}

\begin{abstract}
U radu se analizira zahtjev za izvanredno preispitivanje zakonitosti pravomoćne presude - izvanredno pravno sredstvo uvedeno u hrvatsko upravno sudovanje Zakonom o upravnim sporovima iz 2010. U uvodnom poglavlju rada ističe se osnovni ratio te najvažniji problemi u primjeni zahtjeva za izvanredno preispitivanje zakonitosti pravomoćne presude. Nakon toga, institut se podrobnije razmatra, u prvom redu opisujući i analizirajući razvoj pozitivno-pravnog uređenja instituta. Posebno poglavlje rada posvećeno je analizi mogućnosti primjene zahtjeva za izvanredno preispitivanje zakonitosti pravomoćne presude protiv odluke Visokog upravnog suda kojom se odlučuje o zakonitosti općeg akta. U zaključnom poglavlju rada naglašava se važnost instituta za zaštitu subjektivnih prava i javnog interesa te ukazuje na moguća normativna poboljšanja instituta.
\end{abstract}

Ključne riječi: zahtjev za izvanredno preispitivanje pravomoćne presude, upravni spor, Visoki upravni sud Republike Hrvatske, Vrhovni sud Republike Hrvatske

\section{UVOD}

Zahtjev za izvanredno preispitivanje zakonitosti pravomoćne presude (u nastavku rada: Zahtjev) „novo“ je izvanredno pravno sredstvo uvedeno u hrvatsko upravno sudovanje Zakonom o upravnim sporovima iz 2010. ${ }^{1}$ (u nastavku rada: ZUS).

Riječ „novo“ ispred instituta o kojem govorimo mora biti u navodnim znacima jer mu u hrvatskome pravu prethode dva instituta koja su mu vrlo slična - zahtjev za izvanredno preispitivanje sudske odluke (koji je postojao u socijalističkoj Jugoslaviji) i zahtjev za zaštitu zakonitosti (koji je postojao u socijalističkoj Jugoslaviji, ali i u samostalnoj Republici Hrvatskoj do 2012.). ${ }^{2}$

Zakonsko uređenje instituta ukazuje na očitu namjeru zakonodavca Zahtjevom prvenstveno ostvariti odredbu Ustava Republike Hrvatske ${ }^{3}$ (u nastavku rada: Ustav)

1 Zakon o upravnim sporovima (NN 20/10, 143/12, 152/14).

2 O navedenim pravnim sredstvima opsežno v. u: Medvedović, Dragan, ,Zahtjev za izvanredno preispitivanje sudske odluke u upravnom sporu“, Zbornik Pravnog fakulteta Sveučilišta u Rijeci, 4 (1983.), str. 251-265, Mirovski, Ljupčo K., „Vanredna pravna sredstva u upravnom sporu - Predlozi za izmenu“, Pravni život, Beograd, 5 (1980.), str. 29 - 46 i Borković, Ivo, Upravno pravo, Narodne novine, Zagreb, 2002., str. 517 i 518.

3 Ustav Republike Hrvatske (NN 56/90, 135/97, 113/00, 28/01, 76/10, 5/14). 
Dr. sc. Marko Šikić: Primjena zahjeva za izvanredno preispitivanje zakonitosti pravomoćne presude Zbornik radova Pravnog fakulteta u Splitu, god. 54, 1/2017., str. 179.-201.

temeljem koje Vrhovni sud Republike Hrvatske (u nastavku: Vrhovni sud), kao najviši sud, „osigurava jedinstvenu primjenu prava i ravnopravnost svih u njegovoj primjeni“. ${ }^{4}$

Naime, stranke iz upravnoga spora mogu korištenje Zahtjeva tek inicirati jer Državnom odvjetništvu Republike Hrvatske (u nastavku rada: DORH) samo predlažu podnošenje Zahtjeva Vrhovnome sudu. ${ }^{5}$ DORH, također, Zahtjev može podnijeti i po službenoj dužnosti. Dakle, konačno korištenje Zahtjeva ovisi isključivo o prosudbi DORH-a o postojanju ili nepostojanju razloga za podnošenje Zahtjeva Vrhovnom sudu.

Ovakav je zakonodavčev pristup djelomično opravdan i logičan - željelo se izbjeći opasnost da nezadovoljne stranke iz upravnog spora pretjerano opterećuju Vrhovni sud svojim izravnim zahtjevima za preispitivanje sudskih odluka. ${ }^{6} \mathrm{~S}$ obzirom na potencijalnu dvostupanjsku zaštitu i u upravnom postupku i u upravnom sporu te na dugotrajnost postupaka koju takva zaštita može proizvesti, uređenje kojim se onemogućuje stranke izravno koristiti Zahtjev dodatno se može opravdati i razumjeti.

No, s obzirom na to da je cilj ZUS-a primarno zaštititi subjektivna prava građana, ${ }^{7}$ potrebno je razmotriti u kojoj je mjeri zaštita takvih prava omogućena normiranjem Zahtjeva. Prema našem stanovištu, koje se velikim dijelom nadovezuje na argumentirane stavove i drugih autora, ${ }^{8}$ takva je zaštita velikim dijelom izostala. Ovakva se tvrdnja naročito odnosi na razdoblje primjene ZUS-a do stupanja na snagu Zakona o izmjenama i dopunama Zakona o upravnim sporovima iz prosinca 2014. ${ }^{9}$ (u nastavku rada: Novela ZUS-a 2014.). Stoga ćemo u radu veliku pozornost

4 V. čl. 116. st. 1. Ustava.

5 V. čl. 78. st. 1. ZUS-a.

6 V. Đerđa, Dario, Šikić, Marko, Komentar Zakona o upravnim sporovima, Novi informator, Zagreb, 2012., str. 293-294.

7 V. čl. 2. st. 1. ZUS-a.

„Cilj Zakona je „osigurati sudsku zaštitu prava i pravnih interesa fizičkih i pravnih osoba i drugih stranaka povrijeđenih pojedinačnim odlukama ili postupanjem javnopravnih tijela ... Tom cilju podređena je cjelokupna regulacija upravnog spora - od legitimacije za pokretanje spora, položaja tužitelja i zainteresiranih osoba, tijek postupka - posebice osiguranje usmene rasprave, ovlasti suda da sam utvrđuje činjenično stanje, da odlučuje o meritumu - pravu, obvezi ili pravnom interesu tužitelja (spor pune jurisdikcije) te konačno osiguranje izvršenja sudske odluke.

Tek je u drugom planu osiguranje objektivnog prava. Objektivno pravo, u pravilu, štiti se kroz odlučivanje o subjektivnim pravima tužitelja. Štiteći subjektivna prava tužitelja povrijeđena pojedinačnim odlukama ili postupanjem javnopravnih tijela, štiti se objektivni pravni poredak. Samo malobrojnim normama ZUS-a (npr. ocjena zakonitosti općih akata) primarni je cilj zaštita objektivnog prava, a ne subjektivnog prava. No, i u tim se slučajevima kroz zaštitu objektivnog prava štite subjektivna prava fizičkih i pravnih osoba." Medvedović, Dragan, Novi sustav upravnog sudovanja “, u: ibid., str. 32.

8 V. Šprajc, Ivan, „Zahtjev za izvanredno preispitivanje zakonitosti pravomoćne presude: Novo pravno sredstvo u hrvatskom Zakonu o upravnim sporovima“, Sveske za javno pravo, 9 (2012.), str. 5880, Staničić, Frane, „Mogućnost primjene izvanrednog preispitivanja zakonitosti pravomoćne presude protiv odluka Visokog upravnog suda - u upravnom sporu ocjene zakonitosti općeg akta“, Informator, 6399 (2016.), str. 13-15.

9 Zakon o izmjenama i dopunama Zakona o upravnim sporovima (NN 152/14). ZUS je noveliran i Zakonom o izmjenama i dopunama Zakona o upravnim sporovima (NN 143/12, u nastavku rada: Novela 
posvetiti upravo analizi pozicije stranaka iz upravnog spora u inicijalnim i kasnijim fazama pokretanja i postupanja po Zahtjevu.

Konačno, u praksi se pojavilo i zanimljivo i složeno pitanje mogućnosti primjene Zahtjeva protiv odluke Visokog upravnog suda kojom se odlučuje o zakonitosti općeg akta. Zbog toga ćemo u posebnom poglavlju rada opsežnije razmatrati i navedenu problematiku.

\section{ZAHTJEV KAO PRAVNO SREDSTVO PRIJE NOVELA ZUS-A 2012. I 2014.}

Zahtjev je uređen u trećem dijelu ZUS-a pod naslovom „Pravni lijekovi“ i to u posebnoj, trećoj, glavi koja je naslovljena upravo „Zahtjev za izvanredno preispitivanje zakonitosti pravomoćne presude“. Navedena se glava sastoji samo od jednog članka, 78., koji nosi naziv „Podnošenje zahtjeva i odlučivanje“.

U tekstu ZUS-a, prije izmjena učinjenih Novelama ZUS-a 2012. i 2014., čl. 78. glasio je:

„(1) Stranke u upravnom sporu mogu zbog povrede zakona predložiti Državnom odvjetništvu Republike Hrvatske podnošenje zahtjeva za izvanredno preispitivanje zakonitosti pravomoćne sudske odluke upravnog suda ili Visokog upravnog suda.

(2) Zahtjev za izvanredno preispitivanje zakonitosti pravomoćne sudske odluke može podnijeti Državno odvjetništvo Republike Hrvatske u roku od šest mjeseci od dana dostave pravomoćne sudske presude strankama. Državno odvjetništvo Republike Hrvatske ovaj zahtjev može podnijeti i po službenoj dužnosti.

(3) O zahtjevu odlučuje Vrhovni sud Republike Hrvatske u vijeću koje čini pet sudaca.

(4) Ako Vrhovni sud Republike Hrvatske usvoji zahtjev, može ukinuti presudu $i$ vratiti predmet na ponovno rješavanje ili preinačiti presudu. "

Kako smo i naglasili u uvodu rada, vidljivo je kako je ovakvim zakonodavčevim pristupom naglasak stavljen na osiguravanje jedinstvene primjene prava i ravnopravnosti građana od strane Vrhovnoga suda, dok je uloga Zahtjeva kao pravnog sredstva koji je na raspolaganju i građanima, kao i drugim strankama u upravnom sporu, ostala u drugom planu. 
Dakle, kako bi se navedena ustavna funkcija Vrhovnog suda mogla ostvariti, zakonodavac je predvidio postupak prema kojemu stranke u upravnom sporu (radi se, prema tome, o tužitelju, tuženiku i zainteresiranoj osobi), ${ }^{10}$ a zbog povrede zakona (povrede postupovnog i materijalnog prava, pogrešno i nepotpuno utvrđenih činjenica i činjeničnog stanja, te nenadležnosti) ${ }^{11}$ mogu DORH-u samo predložiti podnošenje Zahtjeva. DORH može podnijeti Zahtjev i po službenoj dužnosti.

DORH je, prema tome, jedini ovlašten na podnošenje Zahtjeva, i to u roku od šest mjeseci od dana dostave pravomoćne sudske presude strankama.

Ovakvom su zakonskom uređenju neposredno nakon stupanja ZUS-a na snagu ${ }^{12}$ upućeni vrlo argumentirani prigovori.

Prigovori su prvenstveno isticali podnormiranost zakonskog teksta koji Zahtjev uređuje, tj. postojanje većeg broja pravnih praznina, ${ }^{13}$ što je u konačnici u prvom redu prouzročilo spomenuto narušavanje dvostranosti Zahtjeva kao pravnoga sredstva. ${ }^{14}$ Također, uređenju Zahtjeva uputio se i prigovor većih gramatičkih, nomotehničkih i smislenih nepodudarnosti i neusklađenosti vezanih uz korištenje termina „,sudska presuda“ i ,sudska odluka“. ${ }^{15}$

što se tiče posljednjeg navedenog prigovora u tekstu ZUS-a postojala su očita proturječja i neusklađenost već iz samog naziva Zahtjeva kao pravnog sredstva (,Zahtjev za izvanredno preispitivanje zakonitosti pravomoćne presude“) kojim se izravno navodila isključivo sudska presuda kao objekt Zahtjeva i zakonskog uređenja instituta u čl. 78. st. 1. i 2. ZUS-a u kojima se naizmjence spominjala i sudska presuda i sudska odluka. ${ }^{16}$

10 V. Šprajc, op. cit. (bilj. 8), str. 58. i str. 68. i 69. Šprajc ispravno primjećuje kako je pozicija DORH-a, kao jedinog ovlaštenog podnositelja Zahtjeva, vrlo problematična u situacijama kada je DORH bio strankom u prethodno pravomoćno okončanom upravnom sporu. Naime, tada je DORH kao stranka iz upravnog spora izravno privilegiran u odnosu na ostale stranke.

11 V. ibid., str. 65. Šprajc naglašava kako bi DORH, kao jedini ovlašteni podnositelj Zahtjeva, i Vrhovni sud, kao sud nadležan za odlučivanje o Zahtjevu, trebali koncentrirati svoje djelovanje u postupku po Zahtjevu isključivo na one povrede koje svojim intenzitetom, pa onda i mogućim posljedicama na prava i slobode pravnih subjekata, nadilaze potrebu zaštite egzistencije pravomoćne sudske odluke. Isticanje povrede postupovnih i materijalnih pitanja te pogrešno i nepotpuno utvrđenih činjenica ili činjeničnog stanja, kao i nenadležnosti kao razloga za podnošenje Zahtjeva v. u: Staničić, op. cit. (bilj. 8), str. 13.

12 ZUS je nakon gotovo dvogodišnjeg vacatio legis stupio na snagu 1. siječnja 2012.

13 V. Šprajc, op. cit. (bilj. 8), str. 60-64.

14 Šprajc ističe kako je zahtjev izvanredno (može ga se podnijeti tek nakon pravomoćnosti osporavane presude), devolutivno (o njemu odlučuje najviši sud u Republici Hrvatskoj), nesuspenzivno (korištenje Zahtjeva ni na koji način ne utječe na stupanje na snagu odluke koja se zahtjevom pobija), jednostranačko (može ga podnijeti isključivo DORH) i samostalno (podnosi se samostalno i nevezano za bilo koje drugo pravno sredstvo) pravno sredstvo. Kriterij dvostranosti (protivniku pravnog sredstva omogućeno je izjašnjavanje o zahtjevima podnositelja pravnog sredstva) upitan je, ali Šprajc smatra da se i njega može zadovoljiti primjenom načela izjašnjavanja stranke utemeljenog čl. 6. ZUS-a. V. Šprajc, op. cit. (bilj. 8), str. 59-60. O dvostranosti Zahtjeva opširnije ćemo pisati u nastavku rada.

15 V. ibid., str. 65-66, Staničić op. cit. (bilj. 8), str. 13.

16 Čl. 78. st. 1. ZUS-a govorio je o sudskoj odluci dok iz je čl. 78. st. 2. čak bilo moguće zaključiti da je sam naziv instituta zapravo „Zahtjev za izvanredno preispitivanje zakonitosti pravomoćne sudske odluke", a da bi se kasnije u istom stavku nastavilo govoriti o sudskoj presudi. 
Pojam sudska odluka zakonski je širi pojam koji u sebi obuhvaća dva uža pojma - presudu i rješenje. ${ }^{17}$ Presudom se odlučuje o tužbenom zahtjevu koji se odnosi na glavnu stvar i sporedna traženja ${ }^{18}$ dok se rješenjem odlučuje o postupovnim pitanjima ${ }^{19}$.

S obzirom na činjenicu da je ZUS predvidio mogućnost da se o važnim postupovnim pitanima odlučuje rješenjem, ali, što je još i važnije, da se rješenjima i okončava upravni spor, ${ }^{20}$ slažemo se s razmišljanjima autora koji se zalažu da se podnošenje Zahtjeva osigura i protiv sudskih presuda i protiv rješenja, tj. protiv svih sudskih odluka. Pristupom kojim bi se Zahtjev mogao podnijeti samo protiv sudskih presuda nejednako bi se tretirali akti koji se donose u vrlo sličnim situacijama te bi se ograničavala mogućnost ispitivanja zakonitosti rješenja kojima se okončava upravni spor. ${ }^{21}$

Zakonodavac je navedena terminološka proturječja i nezgrapnosti pokušao ispraviti Novelama ZUS-a 2012. i 2014. Smatramo kako u takvoj namjeri nije u potpunosti uspio, što ćemo analizirati u sljedećem poglavlju našeg rada.

Upravno-pravna teorija istaknula je, što smo ranije i naveli, kako postojanje pravnih praznina otežava karakteriziranje Zahtjeva kao jednostranog ili dvostranog pravnog sredstva. ${ }^{22}$ Naime, prema navedenom kriteriju, pravna sredstva razlikuju se ovisno o tome mora li se protivniku podnositelja pravnog sredstva omogućiti izjašnjavanje o zahtjevima podnositelja pravnog sredstva. Ako mu se takvo izjašnjavanje omogućuje, radi se o dvostranom pravnom sredstvu, a ako mu se izjašnjavanje ne omogućuje, riječ je o jednostranom pravnom sredstvu. ${ }^{23} \mathrm{~S}$ obzirom na činjenicu da u tekstu ZUS-a nedostaje odredba kojom bi se izričito uređivalo ovo pitanje, ističe se kako odgovor treba potražiti u načelu izjašnjavanja stranke utemeljenog čl. 6. ZUS-a. ${ }^{24}$ Primjenjujući princip regula pro lege, si deficit lex (ako ne postoji pravo, na njegovo mjesto stupa načelo) može se zaključiti da je nakon pokretanja postupka po Zahtjevu nadležni sud dužan omogućiti svim strankama iz

Napominjemo kako slične terminološke nedoumice i lutanja postoje u ZUS-u i u uređenju obnove postupka (v. čl. 76. st. 1. t. 6. i 7.) te da je VUS zbog navedenih nejasnoća zauzeo stajalište da se spor koji je okončan rješenjem ne može obnoviti.

17 V. glavu V. ZUS-a pod naslovom „Sudske odluke“.

18 V. čl. 55. st. 1. ZUS-a.

19 V. čl. 65. st. 1. ZUS-a.

20 Rješenjem se odlučuje i o odbacivanju tužbe kao neuredne (čl. 29. ZUS-a), o odbacivanju tužbe jer ne postoje pretpostavke za vođenje upravnog spora (čl. 30. ZUS-a) i o obustavi upravnog spora (čl. 46. ZUS-a).

${ }_{21}$ V. Šprajc, op. cit. (bilj. 8), str. 65. i 66.

22 V. ibid., str. 60.

23 Ibid.

24 „(1) Prije donošenja presude sud će svakoj stranci dati mogućnost izjasniti se o zahtjevima i navodima drugih stranaka te o svim činjenicama i pravnim pitanjima koja su predmet upravnog spora."

(2) Sud može odlučiti u upravnom sporu bez davanja stranci mogućnosti da se izjasni samo u slučajevima propisanim zakonom.“ (Čl. 6. ZUS-a pod naslovom „Načelo izjašnjavanja stranke“). 
ranije pravomoćno okončanog upravnog spora izjašnjavanje o uloženom Zahtjevu. Navodi se kako bi spomenute stranke Vrhovni sud trebao u postupak uključiti dostavom Zahtjeva te ostavljanjem odgovarajućeg roka za očitovanje. Ako bi se postupalo na opisani način, ističe se, Zahtjev bi se mogao okarakterizirati i kao dvostrano pravno sredstvo. ${ }^{25}$

Zakonodavac je prepoznao postojanje pravne praznine u opisanom dijelu te je Novelom ZUS-a 2014. omogućio izjašnjavanje protivnih stranaka na Zahtjev - o čemu ćemo također opširnije pisati u sljedećem poglavlju rada.

Poseban, vjerojatno i najveći, problem u uređenju Zahtjeva predstavlja pitanja statusa stranke u postupku po Zahtjevu. Naime, jedini ovlašteni podnositelj Zahtjeva je DORH. Dakle, stranke iz pravomoćno okončanog upravnog spora nemaju stranačku legitimaciju na podnošenje Zahtjeva - cjelokupni njihov utjecaj ograničen je samo na prijedlog podnošenja Zahtjeva što ga upućuju DORH-u.

Upravno-pravna teorija ističe kako stranke iz prethodnog upravnog spora po svim važnim kriterijima zaslužuju poziciju stranke i u postupku koji je DORH pokrenuo Zahtjevom. ${ }^{26}$

Naročito se ističe pozicija stranke koja je inicirala korištenje Zahtjeva posebnim podneskom prema DORH-u i pozicija tuženika iz upravnog spora. Dok je prva spomenuta stranka nedvojbeno zainteresirana za konačnu odluku o Zahtjevu, ona neće znati je li DORH pokrenuo postupak pred Vrhovnim sudom, a i bit će prepuštena monopolu DORH-a na isticanje validnih argumenata u postupku po Zahtjevu. ${ }^{27} \mathrm{U}$ pogledu tuženika iz upravnog spora - dakle redovito javnopravnog tijela ${ }^{28}-$ ističe se da se radi o strankama koje su vitalno zainteresirane za pitanje zakonitosti i pravilnosti primjene propisa koji čine pravnu osnovu upravnoga spora. ${ }^{29}$

U pogledu statusa stranke, teorija opširnije upućuje na praksu Europskog suda za ljudska prava u srodnim predmetima u kojima je dotični sud pronašao narušavanje načela ,,jednakosti oružja““. ${ }^{30}$ Zaključuje se da status zainteresiranih osoba (stranaka) moraju imati sve stranke iz prethodnog upravnog spora - u pogledu takvih stranaka zakonskom odredbom došlo je samo do promjene koja se odnosi na nemoguénost izravnog pokretanja postupka po Zahtjevu, ali ne i do gubitka stranačkog statusa - te se ističe da bi svako odstupanje od opisanog pristupa dovelo do povrede prava na pravično suđenje kako ga tumači i shvaća Europski sud za ljudska prava. ${ }^{31}$

25 V. Šprajc, op. cit. (bilj. 8), str. 60.

26 V. Ibid., str. 68-70.

27 Ibid., str. 69.

28 „Tuženik je javnopravno tijelo koje je donijelo ili propustilo donijeti pojedinačnu odluku, postupilo ili propustilo postupiti, odnosno koje je stranka upravnog ugovora." (Čl. 18. ZUS-a)

29 Šprajc, op. cit. (bilj. 8), str. 69.

30 Presude Europskog suda za ljudska prava u slučajevima Yvon (presuda od 24. travnja 2003.) odnosno Martinie protiv Francuske (presuda od 12. travnja 2006.).

31 V. podrobno u: Šprajc, op. cit. (bilj. 8), str. 68-70. 
S ovakvim se argumentima i zaključcima u potpunosti slažemo. S obzirom na činjenicu da je navedeno pitanje ostalo neriješeno i nakon Novela ZUS-a iz 2012. i 2014., opširnije ćemo se problematikom pozabaviti u zaključnom dijelu rada.

Nadalje, ozbiljnu kritiku doživjelo je i vrlo oskudno uređenje samog postupka po Zahtjevu. Analitičari ističu kako bi, uvažavajući načelo učinkovitosti, ${ }^{32}$ načelo izjašnjavanja stranke te načelo usmene rasprave ${ }^{33}$, sadržana u ZUS-u, postupak morao biti proveden učinkovito uz obvezno pružanje mogućnosti strankama očitovati se o svim bitnim pitanjima konkretnog postupka te uz provođenje usmene rasprave. ${ }^{34}$ Poseban problem, naglašava se, predstavlja izostanak ikakvog zakonskog upućivanja za odabir jedne od zakonskih mogućnosti - ukidanja presude i vraćanja predmeta na ponovno rješavanje ili preinačavanja presude - od strane Vrhovnog suda a povodom usvajanja Zahtjeva. ${ }^{35}$ Također, naglašava se i neuređenost pitanja mogućnosti odricanja i odustanka od Zahtjeva ${ }^{36}$ kao i izostanak regulacije izuzeća sudaca koji odlučuju o Zahtjevu. ${ }^{37}$

Kako su i neka (većina) od navedenih pitanja nakon Novela ZUS-a iz 2012. i 2014. i dalje ostala neodgovorena, u sljedećim poglavljima rada najvažnijima od tih pitanja posvetit ćemo značajniju pozornost.

\section{NOVELE ZUS-A 2012. i 2014.}

\section{a) Novela ZUS-a 2012.}

Zakonodavac je Novelom ZUS-a 2012. ${ }^{38}$ intervenirao u Zahtjev u dva smjera - $u$ čl. 78. st. 1. i 2. ZUS-a pojam „sudske odluke“ zamijenio je pojmom ,presuda“, te je iza stavka 3. dodao novi stavak 4. (čime je dotadašnji stavak 4. postao stavak 5.) koji glasi:

„(4) Sud protiv čije presude je podnesen zahtjev iz stavka 2. ovog članka $i$ javnopravno tijelo kao tuženik dužni su bez odlaganja dostaviti Vrhovnom sudu Republike Hrvatske, na njegov zahtjev, sve spise predmeta."

32 ,Sud će upravni spor provesti brzo i bez odugovlačenja, uz izbjegavanje nepotrebnih radnji i troškova, onemogućit će zlouporabu prava stranaka i drugih sudionika u sporu te će odluku donijeti u razumnom roku." (Čll. 8. ZUS-a).

33 „(1) U upravnom sporu sud odlučuje na temelju usmene, neposredne i javne rasprave.

(2) Sud može odlučiti u upravnom sporu bez održavanja rasprave samo u slučajevima propisanim ovim Zakonom.“ (Čl. 7. ZUS-a).

${ }_{34}$ V opsežno u: Šprajc, op. cit. (bilj. 8), str. 73-79. i 80.

35 Ibid., str. 77-79. i 80.

36 Ibid., str. 71-73.

37 Ibid., str. 76-77.

38 Čl. 16. Novele 2012. 
Generalno, možemo zaključiti kako je Novelom ZUS-a 2012. u uređenju Zahtjeva učinjen korak unatrag. Naime, iako je dodanim stavkom 4. učinjena korisna nadopuna postojećeg uređenja postupka po Zahtjevu, zamjenom pojma „sudska odluka“" pojmom ,presuda“" zakonodavac je nepotrebno suzio doseg Zahtjeva samo na pravomoćne sudske presude. No, Novelom ZUS-a 2014., što ćemo pokazati u nastavku rada, ovakav pristup označavanja akta protiv kojega je moguće podnijeti Zahtjev napušten je te je zakonodavac predvidio mogućnost izjavljivanja Zahtjeva i protiv sudskih presuda i protiv rješenja.

\section{b) Novela ZUS-a 2014.}

Prije nego što navedemo i opišemo izmjene koje su Novelom ZUS-a 2014. učinjene u Zahtjevu, potrebno je napomenuti kako je istom Novelom značajno izmijenjen i poboljšan institut žalbe u upravnom sporu.

Naime, do stupanja na snagu Novele ZUS-a 2014. žalba je u upravnom sporu bila u tolikoj mjeri ograničena da nije pretjerano zaključiti kako je zapravo bila onemogućena. ${ }^{39}$

Posljedica navedenog snažnog ograničavanja bilo je i korištenje instituta koji su strankama služila kao svojevrsni „,surogat“ za žalbu - Zahtjeva i ustavne tužbe.

Đanić, nakon izvršene analize prakse DORH-a i prakse Vrhovnoga suda, ističe kako je ograničavanje prava na žalbu dovelo do konfuzije jer je nezadovoljnim strankama na raspolaganju ostalo podnošenje zahtjeva ili ustavne tužbe koja nije niti smjela niti mogla predstavljati zamjensko pravno sredstvo za žalbu. Zahtjev se, pak, prema mišljenju autorice, nije mogao smatrati djelotvornim pravnim sredstvom za osiguravanje jedinstvene primjene prava zbog toga što stranke nemaju pravo izjaviti taj izvanredni pravni lijek izravno Vrhovnom sudu već isključivo ovise o diskreciji DORH-a. Đanić zaključuje kako se iz prakse DORH-a, sukladno broju ukupno zaprimljenih prijedloga i podnesenih Zahtjeva Vrhovnom sudu, potvrđuje stajalište kako se Zahtjevom kao izvanrednim pravnim lijekom nije moglo kompenzirati ograničene mogućnosti prava na izjavljivanje žalbe, isto kao niti putem ustavne tužbe..$^{40}$

39 O žalbi u upravnom sporu v., između ostaloga: Đanić Čeko, Ana, Žalba u upravnom sporu u hrvatskom i poredbenom pravu, doktorska disertacija, Zagreb, 2016., Đerđa, Dario, Galić, Ante, „Žalba u upravnom sporu“, Zbornik radova Pravnog fakulteta u Splitu, 2 (2014.), str. 339-362, Rajko, Alen, „Širenje prava na žalbu nakon druge novele Zakona o upravnim sporovima“, Hrvatska pravna revija, 15(2015), str. 51-56. i Staničić, Frane, „Nove izmjene i dopune Zakona o upravnim sporovima - korak u pravom smjeru“, Informator, 6340 (2014.), str. 1 i 2.

40 Đanić, analizirajući i podatke po svakoj godini posebno, iznosi podatak kako je u periodu od 1. siječnja 2012. do 31. prosinca 2014. DORH zaprimio ukupno 483 prijedloga za podnošenje Zahtjeva, dok je Vrhovnom sudu podneseno 128 Zahtjeva. Galić, pak, navodi kako je Zahtjev u istom razdoblju „aktiviran“ svega pet puta. V. Galić, Ante, „Učinak druge novele Zakona o upravnim sporovima na upravni spor", Zbornik Pravnog fakulteta Sveučilišta u Rijeci, 1 (2015.), str. 563. Mislimo kako se potonji podatak vrlo vjerojatno odnosi samo na korištenje Zahtjeva protiv upravno-sudskih rješenja. 
Smatramo kako će bitno širenje mogućnosti za izjavljivanje žalbe u upravnom sporu utjecati i na korištenje Zahtjeva u praksi, ali i kako bi moglo otvoriti prostor zakonodavcu za određene normativne izmjene u institutu Zahtjeva - o čemu ćemo podrobnije raspravljati u nastavku rada. ${ }^{41}$

Zakonodavac je Novelom ZUS-a 2014. učinio sljedeće izmjene i dopune instituta Zahtjeva:

U čl. 78. st. 1. ZUS-a iza riječi „pravomoćna presuda“ dodane su riječi „i rješenja“, te su iza stavka 3., dodani novi stavci, 4., 5. i 6. (čime su dotadašnji stavci 4. i 5. postali stavci 7. i 8.):

„(4) Nepravodoban zahtjev ili zahtjev koji je podnijela neovlaštena osoba sud će odbaciti rješenjem.

(5) Ako nadležni sud ne odbaci zahtjev, dostavit će ga protivnoj stranci koja može u roku od 30 dana podnijeti odgovor na zahtjev.

(6) Vrhovni sud Republike Hrvatske rješava o zahtjevu na nejavnoj sjednici, a pobijanu odluku ispituje samo u granicama zahtjeva."

Prema tome, nakon Novela ZUS-a 2012. i 2014., trenutno važeći tekst čl. 78. ZUS-a glasi:

„(1) Stranke u upravnom sporu mogu zbog povrede zakona predložiti Državnom odvjetništvu Republike Hrvatske podnošenje zahtjeva za izvanredno preispitivanje zakonitosti pravomoćne presude i rješenja upravnog suda ili Visokog upravnog suda.

(2) Zahtjev za izvanredno preispitivanje zakonitosti pravomoćne presude može podnijeti Državno odvjetništvo Republike Hrvatske u roku od šest mjeseci od dana dostave pravomoćne sudske presude strankama. Državno odvjetništvo Republike Hrvatske ovaj zahtjev može podnijeti i po službenoj dužnosti.

(3) O zahtjevu odlučuje Vrhovni sud Republike Hrvatske u vijeću koje čini pet sudaca.

(4) Nepravodoban zahtjev ili zahtjev koji je podnijela neovlaštena osoba sud će odbaciti rješenjem.

(5) Ako nadležni sud ne odbaci zahtjev, dostavit će ga protivnoj stranci koja može u roku od 30 dana podnijeti odgovor na zahtjev.

${ }^{41}$ Pribavljeni podaci zaista govore o smanjivanju broja podnesenih prijedloga za podnošenje Zahtjeva te podnesenih Zahtjeva. DORH je, tako, 2015. zaprimio 105 prijedloga te podnio Vrhovnom sudu 16 Zahtjeva, dok je 2016. zaprimio 117. prijedloga i podnio 39 Zahtjeva. 
(6) Vrhovni sud Republike Hrvatske rješava o zahtjevu na nejavnoj sjednici, a pobijanu odluku ispituje samo u granicama zahtjeva.

(7) Sud protiv čije presude je podnesen zahtjev iz stavka 2. ovoga članka $i$ javnopravno tijelo kao tuženik dužni su bez odlaganja dostaviti Vrhovnom sudu Republike Hrvatske, na njegov zahtjev, sve spise predmeta.

(8) Ako Vrhovni sud Republike Hrvatske usvoji zahtjev, može ukinuti presudu $i$ vratiti predmet na ponovno rješavanje ili preinačiti presudu. “

Zakonske izmjene i dopune učinjene Novelom ZUS-a 2014. svakako zaslužuju pohvalu jer je zakonodavac prepoznao kritike i savjete koji su došli iz znanstvene i stručne javnosti te intervencije u zakonski tekst dobrim dijelom učinio i uvažavajući navedene kritike. No, mišljenja smo kako je time učinjen samo prvi korak u unapređenju i usavršavanju instituta Zahtjeva, te se nadamo da će pozitivnih pomaka biti i u nekim mogućim budućim izmjenama i dopunama ZUS-a.

Tako, nakon što su se u izvornom tekstu ZUS-a u pogledu objekta Zahtjeva koristili izrazi „,sudska odluka“ i „sudska presuda“, i nakon što je u Noveli ZUS-a 2012. nepotrebno ,izbačen“ pojam ,sudska odluka“ i zamijenjen pojmom „,presuda“, zakonodavac Novelom ZUS-a 2014. dodavanjem riječi „i rješenja“ u čl. 78. st. 1. konačno želi nedvosmisleno osigurati mogućnost korištenja Zahtjeva protiv svih sudskih odluka.

Međutim, zakonodavac propušta riječi „i rješenja“ na ogovarajućim mjestima dodati i u stavku 2. čl. 78. ZUS-a čime i dalje nastavlja zbunjujući pristup u normiranju objekta Zahtjeva.

Tako i dalje postoji nesuglasje između samog imena Zahtjeva (,Zahtjev za izvanredno preispitivanje pravomoćne sudske presude") i daljnjeg uređenja instituta u kojem se korištenje ovog izvanrednog pravnog sredstva očito želi osigurati i protiv rješenja. Štoviše, čitajući izolirano st. 1. čl. 78. ZUS-a moglo bi se zaključiti da je naziv pravnog sredstva zapravo ,Zahtjev za izvanredno preispitivanje zakonitosti pravomoćne presude i rješenja“", dok bi se, isto tako, izolirano promatrajući st. 2. čl. 78. moglo utvrditi da je objekt Zahtjeva samo sudska presuda.

Spominjanje isključivo sudske presude u st. 2. čl. 78. nameće i pitanje koje ispravno uočava i naglašava Staničić. Naime, rješenja se, ako se donose na raspravi, objavljuju i prema strankama imaju učinak od trenutka objave ${ }^{42}$ pa bi i rok za korištenje Zahtjeva trebao početi od tog trenutka. S obzirom na to da st. 2. čl. 78. ZUS-a propisuje samo rok za podnošenje Zahtjeva protiv sudske presude, teoretski bi se moglo zaključiti da uopće nema roka za podnošenje Zahtjeva protiv rješenja. Staničić, s čime se u potpunosti slažemo, smatra da rok za podnošenje Zahtjeva protiv rješenja postoji i da iznosi šest mjeseci od dana objave rješenja na raspravi, a

${ }^{42}$ V. čl. 65. st. 4. ZUS-a. 
ako se rješenje donosi izvan rasprave da je rok šest mjeseci od dana uredne dostave rješenja stranci. ${ }^{43}$

Smatramo kako su navedena terminološka lutanja zakonodavca vrlo lako rješiva, o čemu ćemo opsežnije izložiti u zaključnom poglavlju rada.

Daljnje upotpunjavanje normiranja postupanja po Zahtjevu (započeta Novelom ZUS-a 2012. dodavanjem odredbe o obvezi spisa predmeta Vrhovnom sudu), učinjena Novelom ZUS-a 2014., također smatramo važnim korakom k unapređenju cjelokupnog instituta Zahtjeva.

Tako je uređenje postupanja po nepravodobnom Zahtjevu ili Zahtjevu koji je podnijela neovlaštena osoba, tj. izričito predviđena mogućnost odbacivanja takvih Zahtjeva od strane Vrhovnog suda, korisna procesna odredba koja popunjava pravnu prazninu u ovom inicijalnom dijelu postupanja Vrhovnog suda po Zahtjevu.

Nadalje, svakako najznačajnija novina uvedena Novelom ZUS-a 2014. jest obvezna dostava Zahtjeva protivnoj strani na odgovor. Zakonodavac je predvidio da stranka odgovor može dati u roku od 30 dana. Smatramo da je davanje odgovora na zahtjev fakultativna obveza protivne strane, te da ona ne može zbog nedavanja odgovora imati izravnih štetnih posljedica. Nadalje, mislimo da je i rok od 30 dana instrukcijski te da se stranci mora omogućiti davanje odgovora do okončanja postupka po Zahtjevu, bez obzira što je to propustila učiniti u navedenom roku. ${ }^{44}$

Opisanom odredbom svakako se poboljšala pozicija svim strankama iz upravnog spora jer im je omogućeno očitovati se o Zahtjevu i bitnim pitanjima konkretnog postupka. No, držimo kako je zakonodavac trebao izričito propisati i mogućnost svim strankama iz upravnog spora sudjelovati u postupku po Zahtjevu. O prijedlozima za moguća normiranja takvog sudjelovanja također ćemo opširnije elaborirati u zaključnom poglavlju rada.

Zakonodavac je, također, Novelom ZUS-a 2014. izrijekom propisao i to da Vrhovni sud o Zahtjevu rješava na nejavnoj sjednici, što je, prema mišljenju upravno-pravne teorije, pogrešno jer je bilo potrebno propisati obvezno održavanje usmene rasprave. Naime, ističe se kako obvezno održavanje usmene rasprave u postupanju po Zahtjevu proizlazi iz čl. 6. Europske konvencije i prakse Europskog suda za ljudska prava u Strasbourgu - Vrhovni sud, naime, u postupku po Zahtjevu odlučuje i o činjeničnim i o pravnim pitanjima, što je situacija kada Europski sud inzistira na održavanju usmene rasprave. ${ }^{45}$

Konačno, zakonodavac je propustio podrobnije razraditi i ovlasti Vrhovnoga suda po usvajanju Zahtjeva.

43 V. Staničić, op. cit. (bilj. 8), str. 13.

44 Nažalost, iz dostupne sudske prakse nije u potpunosti jasno postupa li Vrhovni sud na propisani način. Tako iz presude VSRH Uzpz 12/14-6 od 6. svibnja 2015. proizlazi da Vrhovni sud dostavlja Zahtjeve na odgovor, dok se iz presuda VSRH U-zpz 12/13-6 od 31. ožujka 2015. i VSRH U-zpz 18/14-5 od 1. srpnja 2015. takav zaključak ne može izvući.

45 Opširno i vrlo argumentirano o navedenoj problematici v. u Šprajc, op. cit. (bilj. 8), str. 74-76. 
O posljednjim navedenim problemima i propustima također ćemo opširnije pisati u zaključku rada.

\section{MOGUĆNOST PRIMJENE ZAHTJEVA PROTIV ODLUKA VISOKOG UPRAVNOG SUDA U UPRAVNOM SPORU OCJENE ZAKONITOSTI OPĆEG AKTA}

ZUS je, među brojnim novinama, uveo i mogućnost nadziranja općih akata u okviru upravnog sudovanja. Tako je u čl. 3. st. 2. ZUS-a propisano da je predmet upravnog spora i ocjena zakonitosti općeg akta jedinice lokalne i područne (regionalne) samouprave, pravne osobe koja ima javnu ovlast i pravne osobe koja obavlja javnu službu. Postupak ocjene zakonitosti općih akata ZUS je, pak, uredio u svom šestom dijelu naslovljenom „Ocjena zakonitosti općih akata“ u kojem su propisani način pokretanja postupka ${ }^{46}$ sadržaj i predaja zahtjeva za ocjenu zakonitosti općeg akta, ${ }^{47}$ postupanje Visokog upravnog suda po zahtjevu, ${ }^{48}$ odlučivanje VUS-a o zakonitosti općeg akta, ${ }^{49}$ zahtjev za izmjenu pojedinačne odluke zbog ukidanja općeg akta ${ }^{50} \mathrm{i}$ obustava postupka ocjene zakonitosti općeg akta. ${ }^{51}$

Samo uređenje ocjene zakonitosti općeg akta praksi je nametnulo brojne probleme i nedoumice. ${ }^{52} \mathrm{U}$ našem radu analizirat ćemo samo pitanje mogućnosti korištenja Zahtjeva protiv odluke kojom je VUS rješavao o zakonitosti općeg akta. Dakle, pitanje koje se tiče oba navedena instituta.

46 ,(1) Postupak ocjene zakonitosti općeg akta Visoki upravni sud pokreće na zahtjev fizičke ili pravne osoba ili skupine osoba povezanih zajedničkim interesom ako je pojedinačnom odlukom javnopravnog tijela koja se temelji na općem aktu došlo do povrede njihova prava ili pravnog interesa. Zahtjev se podnosi u roku od 30 dana od dostave odluke.

(2) Postupak ocjene zakonitosti općeg akta Visoki upravni sud može pokrenuti po službenoj dužnosti, na temelju obavijesti građana, pučkog pravobranitelja ili na zahtjev suda.“(Čll. 83. ZUS-a).

47 V. čl. 84. ZUS-a.

48 V. čl. 85. ZUS-a.

49 ,(1) O zakonitosti općeg akta Visoki upravni sud odlučuje na javnoj sjednici.

(2) Visoki upravni sud može održati savjetodavnu raspravu ako ocijeni da je prije odlučivanja o biti stvari potrebna rasprava sa sudionicima postupka, znanstvenicima i drugim stručnjacima.

(3) Sud će presudom ukinuti opći akt, ili pojedine njegove odredbe, ako utvrdi da nije suglasan sa zakonom ili statutom javnopravnog tijela.

(4) Ukinuti opći akt prestaje važiti, odnosno ukinute odredbe općeg akta prestaju važiti danom objave presude Visokog upravnog suda u „Narodnim novinama“.“(Čl. 86. ZUS-a).

50 V. čl. 87. ZUS-a.

51 V. čl. 88. ZUS-a.

52 V. Crnković, Mateja, Objektivni upravni spor u hrvatskom i poredbenom pravu, doktorska disertacija, Zagreb, 2015. i Vezmar Barlek, Inga, „Aktualna pitanja ocjene zakonitosti općih akata“, Zbornik Pravnog fakulteta Sveučilišta u Rijeci, 1 (2015.), str. 547-556. 
Neposredan povod za postavljanje navedenog pitanja u praksi je bila presuda VUS-a ${ }^{53}$ kojom je djelomično usvojio zahtjev stranke i ukinuo dio odredbe čl. 117. st. 2. Odluke o komunalnom redu Grada T. (Sl. gl. Grada T., br. 3/10) u dijelu koji glasi: „, odgovorna osoba u pravnoj osobi““..$^{54}$

Protiv presude VUS-a DORH je podnio Zahtjev, a Vrhovni sud je svojim rješenjem U-zpz 10/14-4 od 4. veljače 2015. (u nastavku rada: Rješenje Vrhovnog suda) odbacio zahtjev kao nedopušten, navodeći da:

\section{„Prema shvaćanju ovoga suda zahtjev za izvanredno preispitivanje zakonitosti pravomoćne presude nije dopušten u postupku radi ocjene zakonitosti općeg akta." ${ }^{55}$}

\section{Ovakvo je stanovište obrazloženo sljedećim argumentima:}

Prema prvom argumentu Vrhovnog suda Zahtjev se ne može primijeniti jer je propisan u glavi trećoj, a ocjena zakonitosti u glavi šestoj ZUS-a, te bi se zbog toga Zahtjev trebao primjenjivati samo u postupku u kojem se radi o nekom pojedinačnom pravu stranke o kojem se odlučuje o upravnom postupku. Drugim riječima u konkretnom se predmetu ne radi o upravnom sporu jer se prema riječima Vrhovnog suda „u upravnom sporu mora raditi o nekom pojedinačnom pravu stranke o kojem se odlučuje u upravnom postupku“. .56

Drugi argument Vrhovnog suda temelji se na tome da se stranka može zaštititi na način da podnese zahtjev nadležnom javnopravnom tijelu za izmjenu pojedinačne odluke javnopravnog tijela kojom je povrijeđeno neko pravo ili pravni interes odgovarajućom primjenom odredaba o obnovi upravnog postupka u roku od tri mjeseca od dana objave presude u Narodnim novinama. ${ }^{57}$

Treći argument kojim Vrhovni sud otklanja svoju nadležnost u tome je što u dijelu u kojem je regulirana ocjena zakonitosti općih akata nije izrijekom ,,propisano da bi se protiv presude Visokog upravnog suda mogao podnositi zahtjev za izvanredno preispitivanje pravomoćne presude". ${ }^{.8}$

53 Presuda Usoz-126/2012-9 od 8. ožujka 2014. (NN 48/14). U nastavku rada: Presuda VUS-a.

54 Staničić ističe kako je Presuda VUS-a kojom je ukinuo dio odredbe čl. 117. st. 2. o komunalnom redu očigledno pogrešna jer je VUS u potpunosti zanemario čl. 11. st. 2. tada važećeg Prekršajnog zakona (NN 107/07, 39/13 i 157/13). Prema tome, ističe Staničić, očigledna je ,povreda zakona“ koju je načinio VUS. V. Staničić, op. cit. (bilj. 8), str. 13 i 14.

$55 \mathrm{~S}$ postupovnog gledišta opravdano je upućen prigovor da u konkretnom postupku nije trebalo donijeti rješenje da se Zahtjev DORH-a odbacuje kao nedopušten. ZUS u čl. 78. st. 4. propisuje da se Zahtjev treba odbaciti kao nedopušten: a) kada je neopravdan ili b) kada ga je podnijela neovlaštena osoba. U konkretnom slučaju ne radi se niti o jednom od dva navedena razloga. Također, ističe se i kako s obzirom na činjenicu da ZUS propisuje samo dva navedena razloga za odbacivanje možemo zaključiti da u svim ostalim situacijama kad Zahtjev podnese ovlaštena osoba protiv pravomoćne sudske odluke upravnog suda ili VUS-a Vrhovni sud mora rješavati. V. ibid., str. 14.

56 V. ibid. i Šikić, Marko, Crnković, Mateja, „Upravnosudska i ustavnosudska kontrola zakonitosti akata jedinica lokalne i područne (regionalne) samouprave“, Zbornik Pravnog fakulteta Sveučilišta u Rijeci, 1 (2016.), str. 443.

57 V. Šikić, Crnković, op. cit. (bilj. 56), str. 444.

58 Ibid., Staničić, op. cit. (bilj. 8), str. 14. 
Upravno-pravna teorija je na Rješenje Vrhovnog suda reagirala vrlo kritički te istaknula pogrešnost opisane argumentacije.

Tako se u pogledu prvog navedenog argumenta ističe kako on predstavlja suprotnost cjelovitom ili holističkom i teleološkom tumačenju zakona, tj. da ni u jednom zakonu ono što je napisano prije ne isključuje ono što je napisano poslije, a ni obrnuto. ${ }^{59}$ Nadalje, navodi se kako je sukladno ZUS-u predmet upravnog spora i ocjena zakonitosti općeg akta jedinice lokalne i područne (regionalne) samouprave, pravne osobe koja ima javne ovlasti i pravne osobe koja obavlja javnu službu ${ }^{60}$ tako da se stanovište Vrhovnog suda prema kojem se u upravnom sporu mora raditi o nekom pojedinačnom pravu stranke protivi postojećem zakonskom uređenju. ${ }^{61}$

Što se tiče drugog argumenta, navodi se kako je on pogrešan u svojoj biti. Naime, zahtjev za izmjenu pojedinačne odluke, temeljem čl. 87. ZUS-a, podnijet će stranke koje su uspjele u postupku pred VUS-om, a ne one koje u tom postupku nisu uspjele, tj. oni podnositelji temeljem čijih je zahtjeva opći akt ukinut pa imaju osnovu za traženje izmjene odluke koja je donesena temeljem nezakonitog općeg akta. Vrhovnom sudu će se, pak, zahtjevom obratiti one stranke koje nisu uspjele u postupku pred VUS-om te je njihov zahtjev odbačen ili odbijen. ${ }^{62}$ Nadalje, vezano uz isti argument, ističe se da Vrhovni sud nije uzeo u obzir konkretnu situaciju u kojoj je VUS nezakonito postupio i ukinuo zakoniti opći akt. Stoga obraćanje javnopravnom tijelu ne predstavlja alternativu za preispitivanje zakonitosti pravomoćne presude VUS-a. ${ }^{63}$

Treći argument, ističe se, moguće je pobiti polazeći od zabrane uskrate pravosuđa odnosno od zabrane pozivanja nadležnog suda na nemogućnost rješavanja predmeta zbog postojanja pravne praznine.${ }^{64}$ Čnjenica da nešto nije izrijekom propisano kao dopušteno ne može samo po sebi značiti da je nedopušteno.

Vezano za navedeni argument, navodi se kako ZUS ne propisuje protiv kojih se i kakvih rješenja i presuda može podnijeti Zahtjev te se prema tome može smatrati da se Zahtjev može koristiti protiv svih presuda i rješenja koja donesu upravni sudovi ili VUS - dakle i presuda i rješenja donesenih u postupku ocjene zakonitosti općeg akta. ${ }^{65}$

Nadalje, Zakon o sudovima ${ }^{66}$ propisuje da Vrhovni sud, između ostaloga, osigurava jedinstvenu primjenu prava i ravnopravnost svih u njegovoj primjeni, ${ }^{67}$ kao i da odlučuje o izvanrednim pravnim lijekovima protiv pravomoćnih odluka

59 V. Šikić, Crnković, op. cit. (bilj. 56), str. 443.

60 V. čl. 3. st. 2. ZUS-a.

${ }_{61}$ V. Staničić, op. cit. (bilj. 8), str. 14.

62 V. Šikić, Crnković, op. cit. (bilj. 56), str. 444.

63 Ibid., Staničić, op. cit. (bilj. 8), str. 15.

${ }^{64}$ Staničić, op. cit. (bilj 8), str. 15, Šprajc, op. cit. (bilj. 8), str. 61.

65 V. Staničić, op. cit. (bilj. 8), str. 15.

66 NN 28/13, 33/15, 82/15 i 82/16.

67 V. čl. 20. t. 1. Zakona o sudovima. 
sudova u Republici Hrvatskoj. ${ }^{68}$ Iz navedenih odredbi, a u kontekstu ZUS-a, prema tome proizlazi da se Zahtjev može koristiti i kad se radi o upravnom sporu o ocjeni zakonitosti općih akata a koji je okončan pravomoćnim rješenjem ili presudom. Također, ako bismo prihvatili stanovište Vrhovnoga suda o nenadležnosti za odlučivanje o Zahtjevu, time bismo istom tom sudu oduzeli mogućnost da osigurava jedinstvenu primjenu prava i ravnopravnost svih u njegovoj primjeni. ${ }^{69}$

Zaključno, navodi se kako argumenti Vrhovnog suda nisu prihvatljivi iz više razloga. U prvom redu, tumačenju ZUS-a nije pristupljeno sistematično i na sveobuhvatan način te je nedopustivo cjepkanje jednog cjelovitog zakona na sastavne dijelove. Nadalje, potrebno je uzeti u obzir da je VUS prva i zadnja instanca u redovnom postupku ocjene zakonitosti općih akata, što znači da je riječ o jednostupanjskom postupku. Upitna je mogućnost podnošenja ustavne tužbe, ${ }^{70}$ a izvanrednog pravnog lijeka, ako se isključi Zahtjev, nema. Također, nikako se zahtjev javnopravnom tijelu ne može poistovjetiti s nekim sudskim sredstvom. Cjelokupni je dojam, ističe se, da Vrhovni sud prilikom donošenja citiranog rješenja ni u jednom trenu nije uzeo u obzir da je svrha objektivnog upravnog spora reguliranog u člancima 83.-88. ZUS-a u ostvarenju objektivne zakonitosti. Prema tome, dakle, ,ta važna svrha objektivnog upravnog spora koja se sastoji u očuvanju objektivne zakonitosti, odnosno u sprečavanju toga da temeljem jednog nezakonitog općenormativnog akta bude donesen neodređen broj nezakonitih pojedinačnih akata uopće nije bila uzimana u obzir, što je pogrešno i kosi se sa svrhom ZUS-a, ali i s ustavnom vrednotom vladavine prava. "“71

Iz ranije opisanih stanovišta vidljivo je kako su autori primarno izložili opravdanoj kritici argumentaciju Vrhovnog suda kojom je on otklonio nadležnost za odlučivanje po Zahtjevu povodom odluka VUS-a u sporovima za ocjenu zakonitosti općih akata. ${ }^{72} \mathrm{U}$ navedenim su kritikama istaknuli važnost osiguravanja pravne zaštite i u vrlo važnom i osjetljivom pitanju ocjene zakonitosti općih akata te takvu zaštitu potražili upravo u Zahtjevu. Međutim, također su naglasili kako bi se Vrhovni sud u odlučivanju po Zahtjevu susreo s brojnim problemima koji proizlaze iz velikog broja pravnih praznina u uređenju Zahtjeva, ${ }^{73}$ te napomenuli

68 V. čl. 20. t. 3. Zakona o sudovima.

69 V. Staničić, op. cit. (bilj. 8), str. 15.

70 U vrijeme pisanja citiranog rada Ustavni sud Republike Hrvatske još se nije bio očitovao o dopustivosti ustavne tužbe. U neposrednom nastavku rada analizirat ćemo stanovišta koje je Ustavni sud Republike Hrvatske kasnije razvio.

71 Šikić, Crnković, op. cit. (bilj. 56), str. 444-445.

72 Stanovišta prema kojima se kontrola odluka VUS-a donesenih u objektivnom upravnom sporu omogućava posredno kroz zaštitu Vrhovnog suda u odlučivanju o pravima i interesima stranaka $u$ subjektivnom upravnom sporu (navedeno stajalište v. u: Berlengi Fellner, Ana, Karlovčan Đurović, Ljiljana, „Pravni lijekovi u objektivnom upravnom sporu“, Informator, 6368 (2015.), str. 3.) također se ne prihvaćaju s ispravnim obrazloženjem da je Vrhovni sud, kada odlučuje o Zahtjevu vezan granicama Zahtjeva. Prema tome, u situacijama kada se takav Zahtjev odnosi na pojedinačni akt, Vrhovni sud nema mogućnosti ulaženja u stajališta VUS-a koja je taj sud izrekao u presudi kojom je odlučio (tj. odbio) o zahtjevu stranke za ocjenom općeg akta. V. o navedenome više u Staničić, op. cit. (bilj. 8), str. 15.

73 V. Staničić, op. cit. (bilj. 8), str. 15. 
kako se (u vrijeme pisanja citiranih radova) Ustavni sud Republike Hrvatske još nije bio očitovao o mogućnosti podnošenja ustavnih tužbi protiv odluka VUS-a u sporovima o zakonitosti općih akata. ${ }^{74}$

S navedenim se stajalištima i kritikama u potpunosti slažemo, no željeli bismo istaknuti i probleme koje bi u praksi moglo izazvati dodavanje još jednog tijela Vrhovnog suda - u i onako već dovoljno zamršenu mrežu odnosa vezanih za ocjenu zakonitosti podzakonskih općenormativnih akata u Republici Hrvatskoj.

Stoga s velikim olakšanjem možemo istaknuti činjenicu da se Ustavni sud očitovao o dopuštenosti ustavnih tužbi protiv odluka VUS-a u sporovima o zakonitosti općih akata. Naime, u svom Rješenju br. U-III-4035/2013 od 26. siječnja $2016 .{ }^{75}$ Ustavni sud je zauzeo stajalište da se presude VUS-a u takvim sporovima mogu osporavati ustavnom tužbom:

„... Iz navedenih odredbi ZUS-a razvidno je da Visoki upravni sud može u dva slučaja odlučivati o zakonitosti općih akata:

- na zahtjev fizičke ili pravne osobe ili skupine osoba povezanih zajedničkim interesom ako je pojedinačnom odlukom javnopravnog tijela koja se temelji na općem aktu došlo do povrede njihova prava ili pravnog interesa $i$

- kada sam utvrdi da je određeni opći akt nezakonit (postupanje ex offo).

... U prvom slučaju postupak ocjene zakonitosti nekog općeg akta provodi se radi zaštite prava ili pravnog interesa fizičke ili pravne osobe ili skupine osoba povezanih zajedničkim interesom koje su zahtjev podnijele. Visoki upravni sud u takvom postupku posredno odlučuje o pojedinačnim pravima, obvezama $i$ pravnim interesima te donosi presude i rješenja, dakle pojedinačne akte. Stoga se i protiv tih presuda i rješenja, nakon njihove pravomoćnosti, može podnijeti ustavna tužba.

U drugom slučaju cilj postupka jest (samo) zaštita objektivnog pravnog poretka. I u tom slučaju presude iz tog postupka se mogu osporavati ustavnom tužbom.

Ustavni sud utvrđuje da se podnošenjem ustavne tužbe, objektivni upravni spor vođen pred Visokim upravnim sudom transformira (postaje) u postupak za zaštitu ustavnih prava pred Ustavnim sudom.

... Osim navedena dva slučaja, postoje i slučajevi u kojima Visoki upravni sud odlučuje u prijelaznom razdoblju, nakon što mu je Ustavni sud dostavio na nadležno postupanje prijedloge za ocjenu zakonitosti pojedinih općih akata koji (više) nisu u nadležnosti Ustavnog suda, nakon stupanja na snagu ZUS-a. Postupanje Visokog upravnog suda u tim slučajevima može se (uz određene

74 Ibid., Šikić, Crnković, op. cit (bilj. 56), str. 444.

75 NN 17/16. Također v. i Rješenje Ustavnog suda br. U-III-6079/13 od 13. srpnja 2016. 
posebnosti) poistovjetiti s postupanjem Visokog upravnog suda na temelju članka 83. stavka 2. ZUS-a.

Svaki od navedena tri slučaja ima svoje specifičnosti o kojima ovisi i mogućnost podnošenja ustavne tužbe i aktivna legitimacija za podnošenje ustavne tužbe, o čemu se odlučuje u svakom pojedinom slučaju.

... Drugo je pitanje, na koje valja odgovoriti u ovom ustavnosudskom postupku, tko je aktivno legitimiran za podnošenje ustavnih tužbi?

Aktivno legitimiran u takvom ustavnosudskom postupku koji se vodi na temelju članka 62. Ustavnog zakona jest pravna ili fizička osoba kojoj su izravno povrijeđena ustavna prava presudom ili rješenjem Visokog upravnog suda koje osporava. Drugim riječima, taj akt mora neposredno utjecati na njegova ustavna prava. Te će se okolnosti ispitivati u svakom pojedinom slučaju povodom podnesene ustavne tužbe.

... Osim toga, presudom ili rjě̌enjem Visokog upravnog suda, koje on donosi na temelju članka 83. ZUS-a, mogu biti povrijeđena i neka specifična prava pojedinih donositelja općih akata. Tako primjerice, jedinici lokalne samouprave može biti ograničena ili narušena njihova Ustavom zajamčena samoupravna pozicija (članci 128. do 131. Ustava, v. rješenje Ustavnog suda broj: U-III-462/2010 od 10. rujna 2013., „Narodne novine” broj 120/13.), dok pojedinim visokoškolskim ustanovama može biti ograničena njihova Ustavom zajamčena autonomija iz članka 67. Ustava. Isto tako, pojedinim vjerskim zajednicama mogu biti ugrožena ustavna prava iz članka 15. Ustava, a političkim strankama prava na političko djelovanje.

Slijedom navedenog, donositelji općih akata pod navedenim su pretpostavkama ovlašteni podnijeti ustavnu tužbu, ali samo ako se njome traži zaštita protiv neustavnih zahvata u njihovo ustavno pravo (primjerice na lokalnu samoupravu, na autonomiju sveučilišta ili na slobodu vjeroispovijesti). Samo se u tom slučaju, dakle, donositeljima općih akata priznaje svojstvo nositelja ustavnih prava, a ne obveznika njihove zaštite."

Smatramo kako je izuzetno važno što je Ustavni sud Republike Hrvatske zauzeo citirano stanovište te ističemo kako se s argumentacijom Ustavnog suda $\mathrm{u}$ potpunosti slažemo. Ovakvim se pristupom osigurala pravna zaštita u jednom, za čitavu zajednicu, vrlo bitnom segmentu. Naime, širokim pristupom u pitanju aktivne legitimacije, Ustavni sud je uspio zaštititi i pojedince, ali i objektivni pravni poredak koji može biti ozbiljno narušen egzistencijom nezakonitih općih akata. 


\section{ZAKLJUČAK - PRIJEDLOZI ZA NORMATIVNO UNAPREĐENJE ZAHTJEVA}

Smatramo kako je iz prethodnih poglavlja razvidno kako se institut Zahtjeva, koji je inicijalno bio postavljen u krajnje rudimentarnom obliku, kroz kasnije zakonodavne intervencije i ustavno-sudsku praksu, ipak značajnije poboljšao i unaprijedio.

No, kako smo to u radu na nekoliko mjesta i istaknuli, određena vrlo važna pitanja i dalje su ostala neriješena. Stoga ćemo u zaključnom poglavlju našeg rada iznijeti nekoliko prijedloga za normativno upotpunjavanje i unapređenje instituta - dakako, bez ikakvih ambicija da naše prijedloge smatramo konačnima i jedinima kojima bi se moglo postići poboljšanje zakonskog uređenja Zahtjeva.

Tako bismo, najprije, željeli istaknuti kako bi institut Zahtjeva trebalo razraditi kroz nekoliko zakonskih članka, a ne samo kroz jedan, kako je to učinjeno u važećem tekstu ZUS-a. Smatramo da bi se kroz razradu instituta kroz nekoliko članaka postigla bolja preglednost i normativno jasno razgraničilo podnošenje Zahtjeva od postupka odlučivanja i donošenje odluka povodom Zahtjeva.

U radu smo ranije naznačili da je terminološka lutanja zakonodavca vezana uz pojmove „odluka“, ,presuda“ $\mathrm{i}$ „,rješenje“ vrlo lako moguće riješiti.

Mislimo, naime, da bi, najprije, trebalo promijeniti zakonski naziv „Zahtjev za izvanredno preispitivanje pravomoćne presude“ u „Zahtjev za izvanredno preispitivanje pravomoćne sudske odluke“, te se dosljedno u zakonskom tekstu koristiti upravo širim pojmom ,sudska odluka“. Iznimku bi jedino trebalo učiniti u normiranju roka za podnošenje Zahtjeva gdje bi se morali koristiti i pojmom sudska presuda i sudsko rješenje kako bi se precizno mogao posebno utvrditi početak tijeka roka za obje navedene sudske odluke.

Na samom početku rada naglasili smo kako smo svjesni razloga zbog kojih je zakonodavac želio institut Zahtjeva urediti na način da izbjegne situacije u kojima bi nezadovoljne stranke mogućim izravnim podnošenjem Zahtjeva pretjerano opterećivale Vrhovni sud.

No, potrebno je istaknuti činjenicu da je Novelom ZUS-a 2014. žalba u upravnom sporu konačno postala pravno sredstvo koje omogućuje strankama pravnu zaštitu protiv nezakonitih odluka prvostupanjskih upravnih sudova. Posljedično, iz pravnoga je života uklonjena potreba korištenja surogatnih pravnih sredstava zaštite protiv takvih odluka - Zahtjeva i ustavne tužbe.

Također, želimo naglasiti kako je postupovni ideal, kojemu se teži, cjelokupan postupak rješavanja upravne stvari što više zadržati u svijetu upravnog postupka, i to već na razini prvostupanjskih tijela, tj. da postupci po pravnim lijekovima, a pogotovo upravno-sudski postupci, budu svedeni na najmanju moguću mjeru. Smatramo da i pravnu normu treba stvarati imajući pred očima navedeni ideal - naravno, uz zadržavanje uvida u stvarnu situaciju i razumnu prosudbu realnih mogućnosti realizacije ovakvog ideala. 
Slijedom navedenih razmišljanja, mislimo da bi u budućim uređenjima Zahtjeva bilo potrebno napustiti pristup prema kojem je jedini ovlašteni podnositelj Zahtjeva DORH tj. bilo bi potrebno normirati mogućnosti da sve stranke iz upravnoga spora mogu podnijeti Zahtjev izravno Vrhovnom sudu. Dakako, i kod ovakvog rješenja zadržala bi se mogućnost da DORH podnese Zahtjev i po službenoj dužnosti.

Držimo da bi se ovakvim pristupom u punoj mjeri omogućilo strankama iz upravnog spora sudjelovanje u postupku povodom Zahtjeva (svakako bi i dalje postojala obveza slanja Zahtjeva na odgovor protivnoj strani) te bi se uklonili problemi koji proizlaze iz postojećeg uređenja - privilegirana pozicija DORH-a i moguće vrijeđanje prava na pravično suđenje. Također, smatramo da bi se navedenim uređenjem Vrhovni sud možda i rasteretilo potrebe za održavanjem usmene rasprave, a za održavanje koje po postojećem uređenju postoje ranije u radu navedeni vrlo jaki argumenti. ${ }^{76}$

Smatramo potrebnim naglasiti kako Zahtjev nije institut istovjetan zahtjevu za zaštitu zakonitosti, ${ }^{77}$ te kako je i ranije u upravnom sporu (u varijanti prilagođenoj tadašnjem federativnom uređenju SFRJ) postojalo izvanredno pravno sredstvo - zahtjev za izvanredno preispitivanje sudske odluke - kojim je stranka mogla izravno tražiti zaštitu od tada najviših sudova. Mislimo da je intencija zakonodavca uređenjem instituta Zahtjeva bila i osigurati strankama iz upravnog spora zaštitu njihovih subjektivnih prava i DORH-u omogućiti ostvarivanje njegovih ustavnih i zakonskih dužnosti i ovlasti. ${ }^{78}$ Da je zakonodavac želio urediti institut čija bi jedina svrha bila samo u realizaciji ustavnih i zakonskih dužnosti i ovlasti DORH-a, pravno bi sredstvo naslovio i uredio kao zahtjev za zaštitu zakonitosti, a ne pod naslovom i na način kako je to učinio Zahtjevom. ${ }^{79}$

76 V. Šprajc, op. cit. (bilj. 8), str. 74-76.

77 „Monopol“ DORH-a za obraćanje Vrhovnom sudu (podnošenje zahtjeva za zaštitu zakonitosti) oslabljen je i u Zakonu o kaznenom postupku (NN 152/08, 76/09, 80/11, 121/11, 91/12, 143/12, 56/13, 145/13, 152/14) uređenjem instituta zahtjeva za izvanredno preispitivanje pravomoćne presude (v. čl. 515.-519. Zakona o kaznenom postupku).

78 „Državno odvjetništvo je samostalno i neovisno pravosudno tijelo ovlašteno i dužno postupati protiv počinitelja kaznenih i drugih kažnjivih djela, poduzimati pravne radnje radi zaštite imovine Republike Hrvatske te podnositi pravna sredstva za zaštitu Ustava i prava." (Čl. 125. st. 1. Ustava Republike Hrvatske).

,(1) Državno odvjetništvo je samostalno i neovisno pravosudno tijelo ovlašteno i dužno postupati protiv počinitelja kaznenih djela i drugih kažnjivih djela, poduzimati pravne radnje radi zaštite imovine Republike Hrvatske te podnositi pravna sredstva za zaštitu Ustava i zakona. " (Čl. 2. st. 1. Zakona o državnom odvjetništvu - NN 76/09, 153/09, 116/10, 145/10, 57/11, 130/11, 72/13, 148/13, 33/15, 82/15).

79 Mislimo da zakonodavac nikako nije želio ulogu stranaka ograničiti samo na obavještavanje DORH-a o potrebi pokretanja Zahtjeva radi zaštite objektivne zakonitosti. Naime, stranke to i tako mogu činiti sukladno Zakonu o Državnom odvjetništvu pa bi bilo nepotrebno tu mogućnost isticati i ZUS-om:

„(1) Državno odvjetništvo dužno je od građana, državnih tijela i pravnih osoba primati prijave, podneske i izjave u stvarima iz svoga djelokruga radi poduzimanja radnji sukladno svojim ovlastima.

(2) Državno odvjetništvo može tražiti od građana obavijesti glede njihovih prijava, podnesaka, pritužbi i predstavki.“(Čl. 50. Zakona o državnom odvjetništvu). 
Stoga smatramo kako bi daljnja evolucija Zahtjeva trebala ići upravo u ranije opisanom smjeru, čime bismo potpunije zaštitili mogućnost zaštite prava stranaka iz upravnog spora, dok bi se DORH-u i dalje ostavila mogućnost podnošenja Zahtjeva po službenoj dužnosti.

Konačno, držimo da bi zakonodavac trebao detaljnije normirati i ovlasti Vrhovnog suda u postupanju po Zahtjevu tj. odgovoriti na pitanje kada će sud koristiti kasatorne (ukidanje osporene odluke i vraćanje na ponovno rješavanje), a kada reformatorske (preinaka osporene odluke) ovlasti. Želimo istaknuti kako se u ovom pitanju slažemo s razmišljanjima koja se zalažu za korištenje kasatornih ovlasti u slučajevima bitne povrede postupovnog prava kao i u slučajevima pogreške u utvrđivanju činjeničnog stanja, a reformatorskih ovlasti u slučajevima pogrešne primjene materijalnog prava, kao i u slučajevima pogrešno utvrđenog činjeničnog stanja. U slučajevima kad Vrhovni sud utvrdi da je odluku donio nenadležni sud mislimo da je potrebno ukinuti osporenu odluku te dostaviti predmet na ponovno rješavanje nadležnome sudu. ${ }^{80}$

Kako smo, nadamo se, u radu pokazali, Zahtjev je u hrvatskom upravno-sudskom postupku zamišljen kao izvanredno pravno sredstvo s dvostrukom zadaćom - zaštite javnog interesa (omogućivanjem Vrhovnom sudu ostvariti svoju ustavnu ulogu jamca jedinstvene primjene zakona i ravnopravnosti građana) i zaštite stranke $u$ upravnom sporu od nezakonitih pravomoćnih odluka upravnih sudova.

Nažalost, realizacija navedenih zamisli, u prvom redu zbog podnormiranosti Zahtjeva, nije uspjela. Međutim, vrlo je važno naglasiti da je Zakonodavac u novelama ZUS-a iz 2012. i 2014. intervenirao u institut Zahtjeva čime su učinjeni važni koraci k postizanju zamišljenih zadaća.

Nadamo se da će zakonodavac i ubuduće nastaviti s unapređivanjem i poboljšavanjem odredbi kojima je uređeno upravno sudovanje te da ce mu naša istraživanja, zaključci i prijedlozi biti barem od male pomoći prilikom regulacije instituta Zahtjeva.

Smatramo da institut Zahtjeva takvu pozornost zakonodavca svakako zaslužuje jer se njime mogu ostvariti mnogobrojne zadaće koje pred sebe postavljaju moderne pravne države, odnosno, najjezgrovitije rečeno, njime se vrlo uspješno mogu zaštititi različiti privatni i javni interesi.

${ }^{80}$ Iibid., str. 79. 


\section{Literatura:}

1. Berlengi Fellner, Ana, Karlovčan Đurović, Ljiljana, „Pravni lijekovi u objektivnom upravnom sporu“, Informator, 6368 (2015.), str. 3. i 4.

2. Borković, Ivo, Upravno pravo, Narodne novine, Zagreb, 2002.

3. Crnković, Mateja, Objektivni upravni spor u hrvatskom i poredbenom pravu, doktorska disertacija, Zagreb, 2015.

4. Đanić Čeko, Ana, Žalba u upravnom sporu u hrvatskom i poredbenom pravu, doktorska disertacija, Zagreb, 2016.

5. Đerđa, Dario, Šikić, Marko, Komentar Zakona o upravnim sporovima, Novi informator, Zagreb, 2012.

6. Đerđa, Dario, Galić, Ante, „Žalba u upravnom sporu“, Zbornik radova Pravnog fakulteta u Splitu, 2 (2014.), str. 339-362.

7. Galić, Ante, „Učinak druge novele Zakona o upravnim sporovima na upravni spor“, Zbornik Pravnog fakulteta Sveučilišta u Rijeci, 1 (2015.), str. 557-577.

8. Medvedović, Dragan, „Zahtjev za izvanredno preispitivanje sudske odluke u upravnom sporu“, Zbornik Pravnog fakulteta Sveučilišta u Rijeci, 4 (1983.), str. 251-265.

9. Medvedović, Dragan, „Novi sustav upravnog sudovanja“, u: Đerđa, Dario, Šikić, Marko, Komentar Zakona o upravnim sporovima, Novi informator, Zagreb, 2012.

10. Mirovski, Ljupčo K., „Vanredna pravna sredstva u upravnom sporu - Predlozi za izmenu“, Pravni život, Beograd, 5 (1980.), str. 29-47.

11. Rajko, Alen, „Širenje prava na žalbu nakon druge novele Zakona o upravnim sporovima“", Hrvatska pravna revija, 15 (2015.), str. 51-56.

12. Staničić, Frane, „Nove izmjene i dopune Zakona o upravnim sporovima - korak u pravom smjeru“, Informator, 6340 (2014.), str. 1 i 2.

13. Staničić, Frane, „Mogućnost primjene izvanrednog preispitivanja zakonitosti pravomoćne presude protiv odluka Visokog upravnog suda - u upravnom sporu ocjene zakonitosti općeg akta“, Informator, 6399 (2016.), str. 13-15.

14. Šikić, Marko, Crnković, Mateja, „Upravnosudska i ustavnosudska kontrola zakonitosti akata jedinica lokalne i područne (regionalne) samouprave“, Zbornik Pravnog fakulteta Sveučilišta u Rijeci, 1 (2016.), str. 423-447.

15. Šprajc, Ivan, ,Zahtjev za izvanredno preispitivanje zakonitosti pravomoćne presude: Novo pravno sredstvo u hrvatskom Zakonu o upravnim sporovima“", Sveske za javno pravo, 9 (2012.), str. 58-80.

16. Vezmar Barlek, Inga, „Aktualna pitanja ocjene zakonitosti općih akata“, Zbornik Pravnog fakulteta Sveučilišta u Rijeci, 1 (2015.), str. 547-556. 


\section{Izvori:}

1. Ustav Republike Hrvatske (NN 56/90, 135/97, 113/00, 28/01, 76/10, 5/14)

2. Zakon o sudovima (NN 28/13, 33/15, 82/15 i 82/16)

3. Zakon o upravnim sporovima (NN 20/10, 143/12, 152/14)

4.

5. Zakon o Državnom odvjetništvu (NN 76/09, 153/09, 116/10, 145/10, 57/11, 130/11, $72 / 13,148 / 13,33 / 15,82 / 15)$

6. Zakonu o kaznenom postupku (NN 152/08, 76/09, 80/11, 121/11, 91/12, 143/12, $56 / 13,145 / 13,152 / 14)$

7. Presuda Europskog suda za ljudska prava u slučaju Yvon protiv Francuske (presuda od 24. travnja 2003.)

8. Presuda Europskog suda za ljudska prava u slučaju Martinie protiv Francuske (presuda od 12. travnja 2006.)

9. Rješenje Ustavnog suda Republike Hrvatske br. U-III-4035/2013 od 26. siječnja 2016.

10. Rješenje Ustavnog suda U-III-6079/13 od 13. srpnja 2016.

11. Rješenje Vrhovnog suda U zpz 10/14-4 od 4. veljače 2015.

12. Presuda Vrhovnog suda Republike Hrvatske U zpz 12/14-6 od 6. svibnja 2015.

13. Presuda Vrhovnog suda Republike Hrvatske U-zpz 12/13-6 od 31. ožujka 2015.

14. Presuda Vrhovnog suda Republike Hrvatske U-zpz 18/14-5 od 1. srpnja 2015.

15. Presuda Visokog upravnog suda Usoz-126/2012-9 od 8. ožujka 2014. (NN 48/14) 


\section{APPLICATION OF EXTRAORDINARY EXAMINATION OF THE LEGALITY OF ENFORCEABLE JUDGEMENTS}

This paper analyses the demand for extraordinary examination of the legality of enforceable judgements- extraordinary legal means introduced into Croatian Administrative adjudication with the Administrative Dispute Act of 2010. In the introductory chapter, the fundamental ratio is emphasised as are the most significant problems in the application of demands for extraordinary examination of the legality of enforceable judgements. Then, that institute in more detail is analysed by firstly describing and analysing the development of positive legal regulation of that institute. A separate chapter of this paper is dedicated to the analysis of the possible application of the demand for extraordinary examination of the legality of the enforceable judgement against the decision by the High Administration Court which decides on the legality of the general act. In the concluding chapter, the importance of the institute for the protection of subjective rights and public interest is emphasised and the possible normative improvements to this institute are shown.

Key words: demand for extraordinary examination of enforceable court decisions, administrative disputes, High Administrative Court of the Republic of Croatia, Supreme Court of the Republic of Croatia. 